Review

\title{
Endoscopic Ultrasound for Early Diagnosis of Pancreatic Cancer
}

\author{
Takeichi Yoshida, Yasunobu Yamashita and Masayuki Kitano * \\ Department of Gastroenterology, Wakayama Medical University, 811-1 Kimiidera, Wakayama-city, \\ Wakayama 641-0012, Japan \\ * Correspondence: kitano@wakayama-med.ac.jp; Tel.: +81-73-441-0627; Fax: +81-73-445-3616
}

Received: 10 June 2019; Accepted: 23 July 2019; Published: 24 July 2019

\begin{abstract}
Detection of small pancreatic cancers, which have a better prognosis than large cancers, is needed to reduce high mortality rates. Endoscopic ultrasound (EUS) is the most sensitive imaging modality for detecting pancreatic lesions. The high resolution of EUS makes it particularly useful for detecting small pancreatic lesions that may be missed by other imaging modalities. Therefore, EUS should be performed in patients with obstructive jaundice in whom computed tomography (CT) or magnetic resonance imaging (MRI) does not identify a definite pancreatic lesion. Interest in the use of EUS for screening individuals at high risk of pancreatic cancer, including those with intraductal papillary mucinous neoplasms (IPMNs) and familial pancreatic cancer is growing. Contrast-enhanced EUS can facilitate differential diagnosis of small solid pancreatic lesions as well as malignant cystic lesions. In addition, EUS-guided fine needle aspiration can provide samples of small pancreatic lesions. Thus, EUS and EUS-related techniques are essential for early diagnosis of pancreatic cancer.
\end{abstract}

Keywords: endoscopic ultrasound; contrast-enhanced endoscopic ultrasound; pancreatic cancer

\section{Introduction}

Improving the prognosis of patients with pancreatic cancer is a challenge. Overall, pancreatic cancer has one of the worst prognoses among all cancers [1,2]; however, the prognosis is better if cancer is detected at an early stage. For example, patients with pancreatic cancers $\leq 1 \mathrm{~cm}$ in size at the time of diagnosis have a 5-year survival rate of $80.4 \%$ [3]. Because such small cancers now account for $0.8 \%$ of all pancreatic cancers [3], detection of more small cancers would contribute to improving mortality rates.

Endoscopic ultrasound (EUS), in which the tip of the endoscope contains a high-frequency transducer, provides high resolution images of the pancreas. Indeed, its high resolution in experienced hands enables detection of focal lesions as small as $2-5 \mathrm{~mm}$ [4]. In addition, EUS-related techniques such as contrast-enhanced EUS (CE-EUS) and EUS-guided fine needle aspiration (EUS-FNA) are used for differential diagnosis of pancreatic lesions. Hence, EUS and EUS-related techniques are essential modalities for diagnosis of pancreatic cancers (Figure 1A-E).

Here, we review the current literature with respect to the role of EUS for the diagnosis of pancreatic cancers, particularly small pancreatic cancers. 

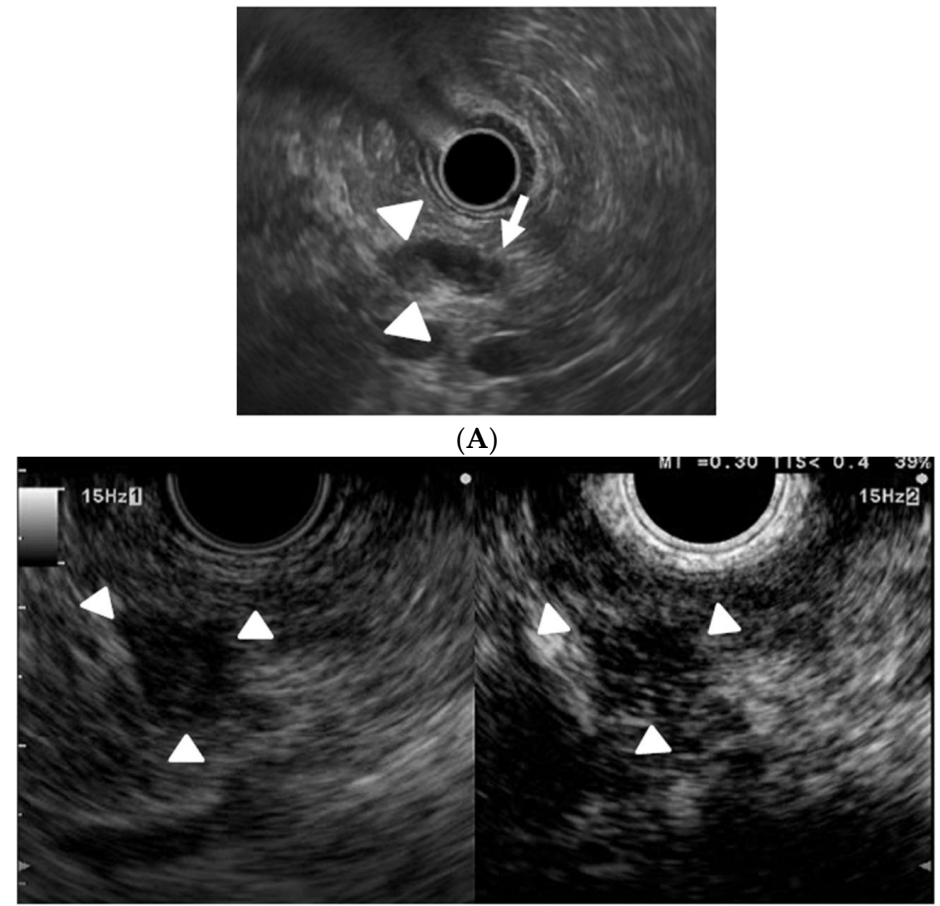

(B)

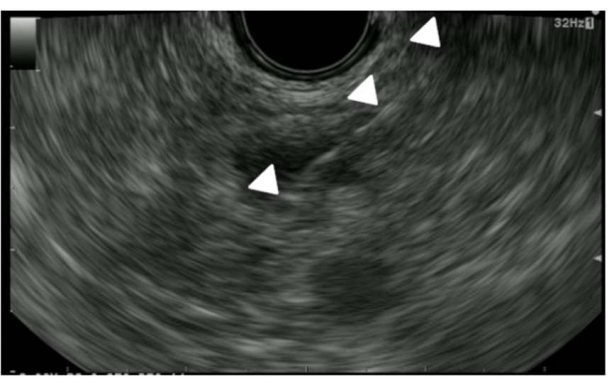

8

(C)

(D)
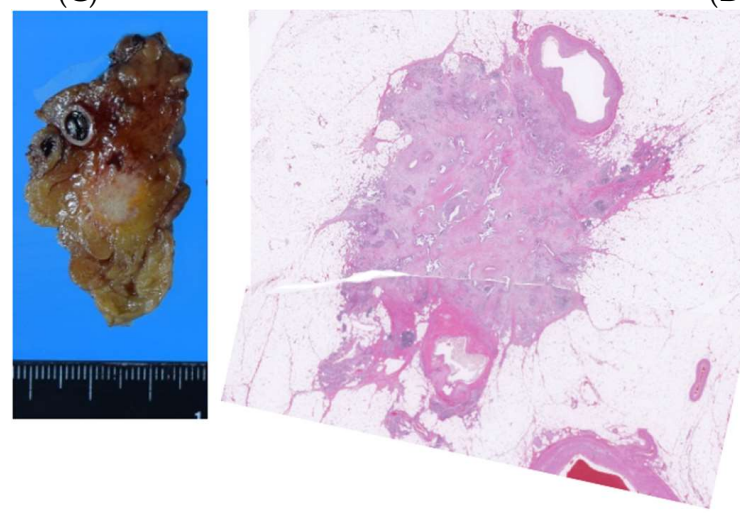

(E)

Figure 1. A case of small pancreatic cancer. (A) Endoscopic ultrasound (EUS) detection of a hypoechoic lesion ( $9 \mathrm{~mm}$, pancreatic body, arrowhead) with distal dilation of the pancreatic duct (arrow); (B) Conventional EUS showing a hypoechoic lesion (arrowhead) at the pancreas body (left) and contrast-enhanced EUS (CE-EUS) showing the lesion has a lower intensity than that of the surrounding tissue (right); (C) EUS-guided fine-needle aspiration (EUS-FNA). The needle targeted the lesion through the stomach (arrowhead); (D) Cytological examination of the aspirated material suggested the presence of an adenocarcinoma (Papanicolaou $\times 1000$ ); (E) The surgically removed lesion (left) and histological findings revealed a final diagnosis of pancreatic cancer (right). 


\section{EUS for Detection of Small Pancreatic Lesions}

Data from a large number of studies reveal that EUS is the most sensitive imaging modality for detection of pancreatic lesions. Overall, the sensitivity of EUS for detecting pancreatic tumors is $94 \%$ ( $n=1170)$, which is consistently higher than that of computed tomography (CT) and transabdominal ultrasound (US) [5].

Although there are limited studies regarding the detection of small pancreatic lesions using EUS, this technique seems to be more useful than other imaging modalities [6-12]. The sensitivity of EUS, $\mathrm{CT}$, and magnetic resonance imaging (MRI) for detecting lesions $<30 \mathrm{~mm}$ in diameter is $93 \%, 53 \%$, and $67 \%$, respectively $(n=49)$ [6]. The sensitivity of EUS for detecting pancreatic tumors $\leq 20 \mathrm{~mm}$ in diameter is higher than that of contrast-enhanced CT ( $94.4 \%$ vs. $50.0 \%$, respectively; $n=36)$ [7], whereas the sensitivity of EUS for detecting pancreatic cancers $\leq 10 \mathrm{~mm}$ in diameter is higher than that of US, CT, and positron emission tomography (PET) (>80\% vs. $17-70 \%, 33-75 \%$, and $50 \%$, respectively) [13]. Of note, EUS can detect pancreatic tumors not identified by other modalities [9-12]. A meta-analysis summarizing four studies $(n=206)$ reported that the sensitivity and specificity of EUS for detecting pancreatic tumors that were indeterminate on multidetector CT (MDCT) were $85 \%$ and $58 \%$, respectively [14].

In clinical practice, a normal pancreas depicted by EUS essentially rules out pancreatic cancer. However, follow-up with EUS or another imaging modality is needed for patients that present with chronic pancreatitis without a definite mass, for patients with a diffusely infiltrating carcinoma, or for patients with a recent episode ( $<4$ weeks) of acute pancreatitis [15-17].

\section{EUS for Surveillance of Asymptomatic High Risk Subjects}

Because EUS provides high resolution images, it would seem reasonable to use it to screen asymptomatic high risk cohorts for pancreatic cancer, including those with premalignant pancreatic lesions (i.e., intraductal papillary mucinous neoplasms (IPMNs)) and those with familial pancreatic cancer [18].

One study has evaluated the utility of EUS for detecting early pancreatic cancers during surveillance of patients with IPMN [19]. The authors screened 102 patients with branch-duct IPMN with EUS over a median period of 3.5 years; seven IPMN-concomitant pancreatic cancers were identified. EUS identified $100 \%$ of the seven IPMN-concomitant cancers, whereas MDCT, MRI, and US identified only $56 \%, 60 \%$, and $39 \%$ of those lesions, respectively. The mean size of the pancreatic tumors was $16 \mathrm{~mm}$, and $85.7 \%$ (6/7) of patients underwent surgery. Thus, frequent follow-up with EUS would enable early detection of pancreatic cancer in patients with IPMNs.

Patients with hereditary and familial pancreatic cancer are another high risk group. Canto et al. screened such individuals and made a blinded comparison of images obtained from CT, MRI, and EUS; they found that EUS was more sensitive (42\%) for detecting pancreatic abnormalities than CT $(11 \%)$ and MRI (33\%) [20].

\section{EUS for Differential Diagnosis of Small Pancreatic Lesions}

CE-EUS is very useful for differential diagnosis of pancreatic lesions. The technique is based on the fact that microbubbles in the contrast agents are disrupted by ultrasound waves, resulting in signals that are detected by the ultrasound imager. A meta-analysis $(n=887)$ revealed that the pooled sensitivity and specificity of CE-EUS were $93 \%$ and $80 \%$, respectively [21]. In contrast, the sensitivity and specificity of EUS alone were $95 \%$ and $53 \%(n=115)$ [22].

Accurate diagnosis of small pancreatic lesions is very important because a relatively high proportion of these lesions are not pancreatic cancers [23]. Very few studies have compared the use of different imaging modalities for differential diagnosis of small pancreatic lesions. However, one study has reported that CE-EUS is particularly useful in this case [8]. The authors provide a detailed description of the diagnostic performance of CE-EUS. With respect to small pancreatic lesions 
$(<2 \mathrm{~cm}$ in diameter, $n=67)$, the sensitivity and specificity of CE-EUS were $91.2 \%$ and $94.4 \%$, respectively. The corresponding values of MDCT were $70.6 \%$ and $91.9 \%$, respectively $(p<0.05)$.

CE-EUS is also useful for differential diagnosis of malignant pancreatic cystic lesions. For example, nodules in cysts associated with IPMN imply pancreatic cancer, although distinguishing mural nodules from mucous clots can be difficult. In this respect, the sensitivity and specificity of CE-EUS are $100 \%$ and $80-97 \%$, respectively, while contrast-enhanced MDCT achieves values of $58-71 \%$ and $100 \%$, respectively $[24,25]$. Additionally, evaluating mural nodules with CE-EUS is useful for estimating the malignant potential of IPMNs [26,27].

Needle-based confocal laser endomicroscopy (nCLE), which provides real-time in vivo imaging of structures, enables the observation of the inner wall of pancreatic cystic lesions during an EUS-FNA procedure. The sensitivity and specificity of nCLE for the diagnosis of pancreatic cystic lesions are $95-98 \%$ and $94-100 \%$, respectively $[28,29]$. It has the potential to play a complementary role in the differential diagnosis of cystic pancreatic lesions. Additionally, more new technologies for contrast enhanced agents have been developed. In mice models, contrast agents specific to tumor vascular marker protein can acquire ultrasound molecular imaging of cancer lesions [30,31]. These promising technologies would help EUS to detect early pancreatic cancers among pancreatic cystic lesions.

\section{EUS for Acquisition of Tissue from Small Pancreatic Tumors}

EUS-FNA is the standard method for obtaining tissue samples from pancreatic lesions because this method has few complications. Data from four meta-analyses suggest that the sensitivity and specificity of EUS-FNA for diagnosis of pancreatic cancer are 85-92\% and 96-98\%, respectively [32-35]. The sensitivity of EUS-FNA for pancreatic cancer in patients with a negative or non-diagnostic sample from a previous endoscopic retrograde cholangiopancreatography (ERCP) exceeds $90 \%$ [36].

Few reports have examined the diagnostic performance of EUS-FNA with respect to small pancreatic lesions. Its sensitivity and specificity for pancreatic lesions $>10$ and $\leq 20 \mathrm{~mm}$ in size are $75.9-92.0 \%$ and $93.8-100 \%$, respectively, whereas those for pancreatic lesions $\leq 10 \mathrm{~mm}$ in size are $40.0-100 \%$ and $80-100 \%$, respectively [37-39]. A few studies have tried to examine the correlation between the performance of EUS-FNA and lesion size, but the data are contradictory [37-41].

By contrast, clinical practice guidelines from the National Comprehensive Cancer Network (NCCN) and the European Society for Medical Oncology (ESMO), along with a consensus statement by the International Study Group of Pancreatic Surgery, propose that proof of malignancy from a biopsy is not required for removal of early resectable pancreatic cancers [42-44]. Surgical resection should not be delayed when there is high clinical suspicion of pancreatic cancer. However, the definition of "high clinical suspicion of pancreatic cancer" seems obscure. Nearly $10 \%$ of resected specimens considered preoperatively as pancreatic cancer turn out to be other types of lesions, such as focal chronic pancreatitis, autoimmune pancreatitis, pancreatic tuberculosis, and pancreatic lymphoma $[45,46]$. New fine needle biopsy devices have been developed to improve tissue acquisition, and three types of fine needle biopsy (FNB) needles are currently available [47-52]. Needles with reverse bevel design (ProCore, Cook Medical, Bloomington, Indiana) have resulted in better histologic evaluation ( $81.1 \%$ vs. $69.4 \%$, $p=0.048$ ) [49] or a smaller number of passes required for diagnosis [50] than the standard FNA needles. Needles with a Franseen tip design (Acquire, Boston Scientific Corp, Natick, MA, USA) and those with a fork-tip design (SharkCore, Medtronic, Minneapolis, MN, USA) can provide larger samples than that of standard needles [51,52], and the performance of those two were comparable in yielding histologic tissue [48]. Additionally, micro-forceps through an EUS 19-guage needle might be promising for tissue acquisition in pancreatic cystic lesions [53]. Taking into consideration overall mortality and morbidity after pancreatic surgery [54], differential diagnosis using CE-EUS is very important to ensure that patients do not undergo unnecessary surgery. Additionally, because small pancreatic lesions are often difficult to identify and target, CE-EUS might help to identify the EUS-FNA target in small pancreatic lesions as well as large ones [8,55]. 


\section{Conclusions}

EUS is an essential modality for identifying early pancreatic cancer. CE-EUS improves characterization of pancreatic lesions detected on EUS, and EUS-FNA can confirm a pancreatic tumor with high sensitivity and specificity.

Funding: The study was supported by a Grant-in-Aid for Scientific Research from the Japan Society for the Promotion of Science (JSPS KAKENHI Grant Number JP16K09410).

Conflicts of Interest: M.K. received a speaker's fee from the Olympus Corporation. The other authors declare no conflicts of interest relevant to this article.

\section{References}

1. The Editorial Board of the Cancer Statistics in Japan. Cancer Registry and Statistics. Cancer Information Service NCCJ (2018) Cancer Statistics in Japan. Foundation for Promotion of Cancer Research (FPCR), 2017. Available online: https://ganjoho.jp/en/professional/statistics/brochure/2017_en.html? (accessed on 1 June 2019).

2. Noone, A.M.; Howlader, N.; Krapcho, M.; Miller, D.; Brest, A.; Yu, M.; Ruhl, J.; Tatalovich, Z.; Mariotto, A.; Lewis, D.R.; et al. SEER Cancer Statistics Review, 1975-2015. Published; 2018. Available online: https: //seer.cancer.gov/csr/1975_2015/ (accessed on 1 June 2019).

3. Egawa, S.; Toma, H.; Ohigashi, H.; Okusaka, T.; Nakao, A.; Hatori, T.; Maguchi, H.; Yanagisawa, A.; Tanaka, M. Japan pancreatic cancer registry; 30th year anniversary: Japan pancreas society. Pancreas 2012, 41, $985-992$. [CrossRef] [PubMed]

4. Rösch, T.; Lightdale, C.J.; Botet, J.F.; Boyce, G.A.; Sivak, M.V., Jr.; Yasuda, K.; Heyder, N.; Palazzo, L.; Dancygier, H.; Schusdziarra, V.; et al. Localization of Pancreatic Endocrine Tumors by Endoscopic Ultrasonography. N. Engl. J. Med. 1992, 326, 1721-1726. [CrossRef] [PubMed]

5. Kitano, M.; Yoshida, T.; Itonaga, M.; Tamura, T.; Hatamaru, K.; Yamashita, Y. Impact of endoscopic ultrasonography on diagnosis of pancreatic cancer. J. Gastroenterol. 2018, 54, 19-32. [PubMed]

6. Müller, M.F.; Meyenberger, C.; Bertschinger, P.; Schaer, R.; Marincek, B. Pancreatic tumors: Evaluation with endoscopic US, CT, and MR imaging. Radiology 1994, 190, 745-751. [CrossRef] [PubMed]

7. Sakamoto, H.; Kitano, M.; Suetomi, Y.; Maekawa, K.; Takeyama, Y.; Kudo, M. Utility of Contrast-Enhanced Endoscopic Ultrasonography for Diagnosis of Small Pancreatic Carcinomas. Ultrasound Med. Biol. 2008, 34, 525-532. [CrossRef] [PubMed]

8. Kitano, M.; Kudo, M.; Yamao, K.; Takagi, T.; Sakamoto, H.; Komaki, T.; Kamata, K.; Imai, H.; Chiba, Y.; Okada, M.; et al. Characterization of small solid tumors in the pancreas: The value of contrast-enhanced harmonic endoscopic ultrasonography. Am. J. Gastroenterol. 2012, 107, 303-310. [CrossRef] [PubMed]

9. Agarwal, B.; Abu-Hamda, E.; Molke, K.L.; Correa, A.M.; Ho, L. Endoscopic ultrasound-guided fine needle aspiration and multidetector spiral CT in the diagnosis of pancreatic cancer. Am. J. Gastroenterol. 2004, 99, 844-850. [CrossRef] [PubMed]

10. Wang, W.; Shpaner, A.; Krishna, S.G.; Ross, W.A.; Bhutani, M.S.; Tamm, E.P.; Raju, G.S.; Xiao, L.; Wolff, R.A.; Fleming, J.B.; et al. Use of EUS-FNA in diagnosing pancreatic neoplasm without a definitive mass on CT. Gastrointest Endosc. 2013, 78, 73-80. [CrossRef] [PubMed]

11. Deerenberg, E.B.; Poley, J.W.; Hermans, J.J.; Ganesh, S.; Van Der Harst, E.; Van Eijck, C.H.J. Role of endoscopic ultrasonography in patients suspected of pancreatic cancer with negative helical MDCT scan. Dig. Surg. 2012, 28, 398-403. [CrossRef]

12. Meijer, O.L.M.; Weersma, R.K.; van der Jagt, E.J.; van Dullemen, H.M. Endoscopic ultrasonography in suspected pancreatic malignancy and indecisive CT. Neth. J. Med. 2010, 68, 360-364.

13. Yamaguchi, K.; Okusaka, T.; Shimizu, K.; Furuse, J.; Ito, Y.; Hanada, K.; Shimosegawa, T.; Okazaki, K. Committee for Revision of Clinical Guidelines for Pancreatic Cancer of the Japan Pancreas Society. Clinical practice guidelines for pancreatic cancer 2016 from the Japan pancreas society a synopsis. Pancreas 2017, 46, 595-604. [CrossRef] [PubMed] 
14. Krishna, S.G.; Rao, B.B.; Ugbarugba, E.; Shah, Z.K.; Blaszczak, A.; Hinton, A.; Conwell, D.L.; Hart, P.A. Diagnostic performance of endoscopic ultrasound for detection of pancreatic malignancy following an indeterminate multidetector CT scan: A systemic review and meta-analysis. Surg. Endosc. 2017, 31, 4558-4567. [CrossRef] [PubMed]

15. Catanzaro, A.; Richardson, S.; Veloso, H.; Isenberg, G.A.; Wong, R.C.; Sivak, M.V., Jr.; Chak, A. Long-term follow-up of patients with clinically indeterminate suspicion of pancreatic cancer and normal EUS. Gastrointest Endosc. 2003, 58, 836-840. [CrossRef] [PubMed]

16. Bhutani, M.S.; Gress, F.G.; Giovannini, M.; Erickson, R.A.; Catalano, M.F.; Chak, A.; Deprez, P.H.; Faigel, D.O.; Nguyen, C.C. No Endosonographic Detection of Tumor (NEST) Study. The no endosonographic detection of tumor (NEST) study: A case series of pancreatic cancers missed on endoscopic ultrasonography. Endoscopy 2004, 36, 385-389. [CrossRef] [PubMed]

17. Klapman, J.B.; Chang, K.J.; Lee, J.G.; Nguyen, P. Negative predictive value of endoscopic ultrasound in a large series of patients with a clinical suspicion of pancreatic cancer. Am. J. Gastroenterol. 2005. [CrossRef]

18. Canto, M.I.; Harinck, F.; Hruban, R.H.; Offerhaus, G.J.; Poley, J.W.; Kamel, I.; Nio, Y.; Schulick, R.S.; Bassi, C.; Kluijt, I.; et al. International cancer of the pancreas screening (CAPS) consortium summit on the management of patients with increased risk for familial pancreatic cancer. Gut 2013, 62, 339-347. [CrossRef]

19. Kamata, K.; Kitano, M.; Kudo, M.; Sakamoto, H.; Kadosaka, K.; Miyata, T.; Imai, H.; Maekawa, K.; Chikugo, T.; Kumano, M.; et al. Value of EUS in early detection of pancreatic ductal adenocarcinomas in patients with intraductal papillary mucinous neoplasms. Endoscopy 2014, 46, 22-29.

20. Canto, M.I.; Hruban, R.H.; Fishman, E.K.; Kamel, I.R.; Schulick, R.; Zhang, Z.; Topazian, M.; Takahashi, N.; Fletcher, J.; Petersen, G.; et al. Frequent detection of pancreatic lesions in asymptomatic high-risk individuals. Gastroenterology 2012, 142, 796-804. [CrossRef]

21. Yamashita, Y.; Shimokawa, T.; Napoléon, B.; Fusaroli, P.; Gincul, R.; Kudo, M.; Kitano, M. Value of contrast-enhanced harmonic EUS with enhancement pattern for diagnosis of pancreatic cancer: A meta-analysis. Dig. Endosc. 2018, 31, 125-133. [CrossRef]

22. Brand, B.; Pfaff, T.; Binmoeller, K.F.; Sriram, P.V.; Fritscher-Ravens, A.; Knöfel, W.T.; Jäckle, S.; Soehendra, N. Endoscopic ultrasound for differential diagnosis of focal pancreatic lesions, confirmed by surgery. Scand. J. Gastroenterol. 2000, 35, 1221-1228.

23. Dietrich, C.F.; Sahai, A.V.; D’Onofrio, M.; Will, U.; Arcidiacono, P.G.; Petrone, M.C.; Hocke, M.; Braden, B.; Burmester, E.; Möller, K.; et al. Differential diagnosis of small solid pancreatic lesions. Gastrointest. Endosc. 2016, 84, 933-940. [CrossRef] [PubMed]

24. Yamashita, Y.; Ueda, K.; Itonaga, H.; Yoshida, T.; Maeda, H.; Maekita, T.; Iguchi, M.; Tamai, H.; Ichinose, M.; Kato, J. Usefulness of contrast-enhanced endoscopic sonography for discriminating mural nodules from mucous clots in intraductal papillary mucinous neoplasms a single-center prospective study. J. Ultrasound Med. 2013, 32, 61-68. [CrossRef] [PubMed]

25. Harima, H.; Kaino, S.; Shinoda, S.; Kawano, M.; Suenaga, S.; Sakaida, I. Differential diagnosis of benign and malignant branch duct intraductal papillary mucinous neoplasm using contrast-enhanced endoscopic ultrasonography. World J. Gastroenterol. 2015, 21, 6252-6260. [CrossRef] [PubMed]

26. Miyata, T.; Kitano, M.; Omoto, S.; Kadosaka, K.; Kamata, K.; Imai, H.; Sakamoto, H.; Nisida, N.; Harwani, Y.; Murakami, T.; et al. Contrast-enhanced harmonic endoscopic ultrasonography for assessment of lymph node metastases in pancreatobiliary carcinoma. World J. Gastroenterol. 2016, 22, 3381-3391. [CrossRef] [PubMed]

27. Ohno, E.; Hirooka, Y.; Itoh, A.; Ishigami, M.; Katano, Y.; Ohmiya, N.; Niwa, Y.; Goto, H. Intraductal papillary mucinous neoplasms of the pancreas: Differentiation of malignant and benign tumors by endoscopic ultrasound findings of mural nodules. Ann. Surg. 2009, 249, 628-634. [CrossRef] [PubMed]

28. Krishna, S.G.; Hart, P.A.; Malli, A.; Kruger, A.; McCarthy, S.T.; El-Dika, S.; Walker, J.P.; Dillhoff, M.E.; Manilchuk, A.; Schmidt, C.R.; et al. Endoscopic Ultrasound-Guided Confocal Laser Endomicroscopy Increases Accuracy of Differentiation of Pancreatic Cystic Lesions. Clin. Gastroenterol. Hepatol. 2019, 17. S1542-3565(19)30648-2. [CrossRef]

29. Napoleon, B.; Palazzo, M.; Lemaistre, A.I.; Caillol, F.; Palazzo, L.; Aubert, A.; Buscail, L.; Maire, F.; Morellon, B.M.; Pujol, B.; et al. Needle-based confocal laser endomicroscopy of pancreatic cystic lesions: A prospective multicenter validation study in patients with definite diagnosis. Endoscopy 2018. [CrossRef]

30. Bachawal, S.V.; Jensen, K.C.; Wilson, K.E.; Tian, L.; Lutz, A.M.; Willmann, J.K. Breast Cancer Detection by B7-H3-Targeted Ultrasound Molecular Imaging. Cancer Res. 2015, 75, 2501-2509. [CrossRef] 
31. Anderson, C.R.; Rychak, J.J.; Backer, M.; Backer, J.; Ley, K.; Klibanov, A.L. Scvegf microbubble ultrasound contrast agents: A novel probe for ultrasound molecular imaging of tumor angiogenesis. Invest. Radiol. 2010, 45, 579-585. [CrossRef]

32. Hewitt, M.J.; McPhail, M.J.W.; Possamai, L.; Dhar, A.; Vlavianos, P.; Monahan, K.J. EUS-guided FNA for diagnosis of solid pancreatic neoplasms: A meta-analysis. Gastrointest Endosc. 2012, 75, 319-331. [CrossRef]

33. Chen, J.; Yang, R.; Lu, Y.; Xia, Y.; Zhou, H. Diagnostic accuracy of endoscopic ultrasound-guided fine-needle aspiration for solid pancreatic lesion: A systematic review. J. Cancer Res. Clin. Oncol. 2012, 138, 1433-1441. [CrossRef] [PubMed]

34. Puli, S.R.; Kalva, N.; Bechtold, M.L.; Pamulaparthy, S.R.; Cashman, M.D.; Estes, N.C.; Pearl, R.H.; Volmar, F.H.; Dillon, S.; Shekleton, M.F.; et al. Diagnostic accuracy of endoscopic ultrasound in pancreatic neuroendocrine tumors: A systematic review and meta analysis. World J. Gastroenterol. 2013, 19, 3678-3684. [CrossRef] [PubMed]

35. Banafea, O.; Mghanga, F.P.; Zhao, J.; Zhao, R.; Zhu, L. Endoscopic ultrasonography with fine-needle aspiration for histological diagnosis of solid pancreatic masses: A meta-analysis of diagnostic accuracy studies. BMC Gastroenterol. 2016, 16, 108. [CrossRef]

36. Gress, F.; Gottlieb, K.; Sherman, S.; Lehman, G. Endoscopic ultrasonography-guided fine-needle aspiration biopsy of suspected pancreatic cancer. Ann. Intern. Med. 2001, 134, 459-464. [CrossRef] [PubMed]

37. Uehara, H.; Ikezawa, K.; Kawada, N.; Fukutake, N.; Katayama, K.; Takakura, R.; Takano, Y.; Ishikawa, O.; Takenaka, A. Diagnostic accuracy of endoscopic ultrasound-guided fine needle aspiration for suspected pancreatic malignancy in relation to the size of lesions. J. Gastroenterol. Hepatol. 2011, 26, 1256-1261. [CrossRef] [PubMed]

38. Siddiqui, A.A.; Brown, L.J.; Hong, S.K.; Draganova-Tacheva, R.A.; Korenblit, J.; Loren, D.E.; Kowalski, T.E.; Solomides, C. Relationship of pancreatic mass size and diagnostic yield of endoscopic ultrasound-guided fine needle aspiration. Dig. Dis Sci. 2011, 56, 3370-3375. [CrossRef] [PubMed]

39. Haba, S.; Yamao, K.; Bhatia, V.; Mizuno, N.; Hara, K.; Hijioka, S.; Imaoka, H.; Niwa, Y.; Tajika, M.; Kondo, S.; et al. Diagnostic ability and factors affecting accuracy of endoscopic ultrasound-guided fine needle aspiration for pancreatic solid lesions: Japanese large single center experience. J. Gastroenterol. 2013, 48, 973-981. [CrossRef] [PubMed]

40. Ramesh, J.; Kim, H.; Reddy, K.; Eltoum, I.E. Performance characteristic of endoscopic ultrasound-guided fine needle aspiration is unaffected by pancreatic mass size. Endosco. Int. Open. 2016, 4, E434-E438. [CrossRef]

41. Crinò, S.F.; Conti Bellocchi, M.C.; Bernardoni, L.; Manfrin, E.; Parisi, A.; Amodio, A.; De Pretis, N.; Frulloni, L.; Gabbrielli, A. Diagnostic yield of EUS-FNA of small ( $\leq 15 \mathrm{~mm})$ solid pancreatic lesions using a 25-gauge needle. Hepatobiliary Pancreat Dis Int. 2018, 17, 70-74. [CrossRef] [PubMed]

42. Tempero, M.A.; Malafa, M.P.; Al-Hawary, M.; Asbun, H.; Bain, A.; Behrman, S.W.; Benson, A.B.; Binder, E.; Cardin, D.B.; Cha, C.; et al. Pancreatic Adenocarcinoma, Version 2.2017, NCCN Clinical Practice Guidelines in Oncology. J. Natl. Compr. Cancer Netw. 2017, 15, 1028-1061. [CrossRef]

43. Ducreux, M.; Cuhna, A.S.; Caramella, C.; Hollebecque, A.; Burtin, P.; Goéré, D.; Seufferlein, T.; Haustermans, K.; Van Laethem, J.L.; Conroy, T.; et al. Cancer of the pancreas: ESMO Clinical Practice Guidelines for diagnosis, treatment and follow-up. Ann. Oncol. 2015, 26, v56-v68. [CrossRef] [PubMed]

44. Asbun, H.J.; Conlon, K.; Fernandez-Cruz, L.; Friess, H.; Shrikhande, S.V.; Adham, M.; Bassi, C.; Bockhorn, M.; Büchler, M.; Charnley, R.M.; et al. When to perform a pancreatoduodenectomy in the absence of positive histology? A consensus statement by the International Study Group of Pancreatic Surgery. Surgery 2014, 155, 887-892. [CrossRef] [PubMed]

45. Van Heerde, M.J.; Biermann, K.; Zondervan, P.E.; Kazemier, G.; van Eijck, C.H.; Pek, C.; Kuipers, E.J.; van Buuren, H.R. Prevalence of autoimmune pancreatitis and other benign disorders in pancreatoduodenectomy for presumed malignancy of the pancreatic head. Dig. Dis Sci. 2012, 57, 2458-2465. [CrossRef] [PubMed]

46. De la Fuente, S.G.; Ceppa, E.P.; Reddy, S.K.; Clary, B.M.; Tyler, D.S.; Pappas, T.N. Incidence of benign disease in patients that underwent resection for presumed pancreatic cancer diagnosed by endoscopic ultrasonography (EUS) and fine-needle aspiration (FNA). J. Gastrointest. Surg. 2010, 14, 1139-1142. [CrossRef] [PubMed]

47. Facciorusso, A.; Bajwa, H.S.; Menon, K.; Buccino, V.R.; Muscatiello, N. Comparison between 22G aspiration and 22G biopsy needles for EUS-guided sampling of pancreatic lesions: A meta-analysis. Endosc. Ultrasound. 2019. [CrossRef] 
48. Mohan, B.P.; Shakhatreh, M.; Garg, R.; Asokkumar, R.; Jayaraj, M.; Ponnada, S.; Navaneethan, U.; Adler, D.G. Comparison of Franseen and fork-tip needles for EUS-guided fine-needle biopsy of solid mass lesions: A systematic review and meta-analysis. Endosc. Ultrasound. 2019. [CrossRef]

49. Kamata, K.; Kitano, M.; Yasukawa, S.; Kudo, M.; Chiba, Y.; Ogura, T.; Higuchi, K.; Fukutake, N.; Ashida, R.; Yamasaki, T; et al. Histologic diagnosis of pancreatic masses using 25-gauge endoscopic ultrasound needles with and without a core trap: A multicenter randomized trial. Endoscopy 2016, 48, 632-638. [CrossRef] [PubMed]

50. Bang, J.Y.; Hawes, R.; Varadarajulu, S. A meta-analysis comparing ProCore and standard fine-needle aspiration needles for endoscopic ultrasound-guided tissue acquisition. Endoscopy 2016, 48, 339-349. [CrossRef]

51. Bang, J.Y.; Hebert-Magee, S.; Hasan, M.K.; Navaneethan, U.; Hawes, R.; Varadarajulu, S. Endoscopic ultrasonography-guided biopsy using a Franseen needle design: Initial assessment. Dig. Endosc. 2017, 29, 338-346. [CrossRef] [PubMed]

52. Kandel, P.; Tranesh, G.; Nassar, A.; Bingham, R.; Raimondo, M.; Woodward, T.A.; Gomez, V.; Wallace, M.B. EUS-guided fine needle biopsy sampling using a novel fork-tip needle: A case-control study. Gastrointest. Endosc. 2016, 84, 1034-1039. [CrossRef]

53. Barresi, L.; Crinò, S.F.; Fabbri, C.; Attili, F.; Poley, J.W.; Carrara, S.; Tarantino, I.; Bernardoni, L.; Giovanelli, S.; Di Leo, M.; et al. Endoscopic ultrasound-through-the-needle biopsy in pancreatic cystic lesions: A multicenter study. Dig. Endosc. 2018, 30, 760-770. [CrossRef] [PubMed]

54. Gooiker, G.A.; Van Gijn, W.; Wouters, M.W.J.M.; Post, P.N.; Van De Velde, C.J.H.; Tollenaar, R.A.E.M. Systematic review and meta-analysis of the volume-outcome relationship in pancreatic surgery. Br. J. Surg. 2011. [CrossRef]

55. Park, J.S.; Kim, H.K.; Bang, B.W.; Kim, S.G.; Jeong, S.; Lee, D.H. Effectiveness of contrast-enhanced harmonic endoscopic ultrasound for the evaluation of solid pancreatic masses. World J. Gastroenterol. 2014, 20, 518-524. [CrossRef] [PubMed]

(C) 2019 by the authors. Licensee MDPI, Basel, Switzerland. This article is an open access article distributed under the terms and conditions of the Creative Commons Attribution (CC BY) license (http://creativecommons.org/licenses/by/4.0/). 